\title{
Dampak Pelaksanaan Program Pengembangan Desa Mitra Di Sentra Pembibitan Sapi Lokal Di Kabupaten Enrekang
}

\author{
Sudirman Baco, Ratmawati Malaka dan Zulkharnaim \\ Fakultas Peternakan Universitas Hasanuddin, Jl. Perintis Kemerdekaan KM 10, Makassar,90245. \\ E-mail. zulkharnaim@unhas.ac.id
}

\begin{abstract}
Abstrak - Tujuan kegiatan pengabdian kepada masyarakat yang dilaksanakan di Desa Pattondon Salu yakni mengembangkan Desa Pembibitan Sapi Bali. Kegiatan ini diharapkan sebagai stimulus peningkatkan ekonomi masyarakat. Fokus kegiatan antara lain: 1) penerapan teknologi manajemen pemeliharaan sapi induk dan pedet, 2) perbaikan infrastruktur pendukung di desa sentra pembibitan ternak dan 3) perbaikan manajemen kesehatan. Jumlah peternak yang berkontribusi dalam kegiatan ini yakni Kelompok Tani Sipakatuo dan Kelompok Tani Ternak Jaya, dengan jumlah total peternak sebanyak 42 orang. Data perkembangan pelaksanaan kegiatan dikumpulkan dengan melakukan survey dan wawancara menggunakan kuesioner. Data yang terkumpul kemudian dianalisis secara deskriptif. Hasil pelaksanaan kegiatan antara lain 1) jumlah sapi yang dipelihara oleh mitra bertambah dari 59 ekor di tahun 2018 menjadi 79 ekor di tahun 2019. Penambahan ini disebabkan perbaikan manajemen pemeliharaan; 2) kebuntingan sapi potong meningkat sebesar 24,53\% dari tahun 2018 menjadi 69,77\% di tahun 2019; dan 3) perbaikan kesehatan dilaksanakan pada penyakit yang paling sering ditemukan pada ternak, yakni toxocariasis.
\end{abstract}

Kata Kunci: Desa Pattondon Salu; Desa Perbibitan Sapi Bali; kebuntingan; manajemen.

\begin{abstract}
The aim of community service activities carried out in Pattondon Salu Village is to develop the Bali Cattle Breeding Village. This activity is expected to be a stimulus to improve the community's economy. The focus of activities include: 1) the application of farm maintenance management cows and calves, 2) improvement of supporting infrastructure in Cattle Breeding Village and 3) improving health management. The number of farmers contributing to this activity is the Sipakatuo Farmer Group and the Ternak Jaya Farmer Group, with a total of 42 farmers. Data on the progress of the implementation of activities was collected by conducting surveys and interviews using a questionnaire. The collected data is then analyzed descriptively. The results of the implementation of the activities include 1) the number of cattle raised by partners increased from 59 head in 2018 to 79 head in 2019. This increase was due to improved maintenance management; 2) pregnancy cattle increased by $24.53 \%$ from 2018 to $69.77 \%$ in 2019; and 3) health improvements carried out in the most common diseases found in livestock, namely toxocariasis.
\end{abstract}

Key Word: Pattondon Salu Village; the Bali Cattle Breeding Village; pregnancy; management.

\section{PENDAHULUAN}

Pembibitan ternak merupakan upaya pemeliharaan sapi untuk menghasilkan bibit unggul sebagai indukan (parent stock), sebagai ternak komersil (final stock), atau sebagai ternak pengganti (replacement stock). Pembibitan ternak bertujuan untuk meningkatkan populasi ternak yang memiliki kualitas genetik unggul. Dengan demikian pentingnya pembibitan ternak, maka kegiatan pembibitan harus dilaksanakan secara terorganisir dan dengan memanfaatkan potensi SDM, SDA dan sumber daya ternak di suatu lokasi. Pembibitan ternak adalah suatu kegiatan yang membutuhkan biaya yang tidak sedikit, sehingga dengan memanfaatkan potensi disuatu daerah dengan baik maka akan mengurangi biaya yang dibutuhkan. Daerah yang dijadikan sebagai lokasi pembibitan ternak selanjutnya dapat disebut sebagai desa sentra pembibitan ternak.

Kecamatan Maiwa memiliki potensi alam yang meliputi padang penggembalaan seluas 2.336,4 Ha dengan daya tampung sebanyak 5.864 ST (Satuan Ternak) [1]. Berdasarkan data di atas dapat dikatakan bahwa potensi alam di Kecamatan Maiwa sangat berlimpah namun belum termanfaatkan secara optimal, disebabkan jumlah ternak sapi potong tidak sebanyak daya tampungnya. Salah satu desa di Kecamatan Maiwa yakni Desa Pattondon Salu yang memiliki luas 28,61 $\mathrm{Km}^{2}$ dan jumlah penduduk 2.083 orang dengan kepadatan penduduk mencapai $72,8 \%$ pada tahun 2014 [1]. Sebagian besar penduduk berkecimpung disektor pertanian dan peternakan sebagai sumber penghasilan utamanya. Jenis sapi 
potong yang banyak diternakkan oleh masyarakat yakni sapi Bali.

Kondisi peternakan sapi potong di Desa Patondon Salu hingga tahun 2017 masih dikelola secara tradisional yang menyebabkan beberapa masalah, antara lain: 1) Kematian pedet yang banyak dan berat lahir yang kecil; 2) Sapi induk terlambat bunting pasca melahirkan; 3) Kualitas pakan yang rendah; 4) Keterbatasan infrastruktur pendukung; dan 5) Kelembagaan peternak belum efektif menyelesaikan masalah anggotanya. Banyaknya kematian pedet sebelum waktu sapih menjadi masalah yang paling sering ditemukan dan merugikan bagi masyarakat. Selain itu, masalah seperti buruknya kualitas pakan memperparah rekondisi induk pasca melahirkan. Masyarakat sangat membutuhkan adanya inovasi teknologi dalam menyelesaikan masalahnya dan memanfaatkan potensi daerah yang ada di Desa Patondon Salu.

Kegiatan PPDM (Program Pengembangan Desa Mitra) di Desa Pattondon Salu secara umum bertujuan untuk membentuk desa pembibitan sapi lokal. Desa Patondon Salu dicanangkan sebagai Desa Sentra Pembibitan Sapi Lokal, dengan memanfaatkan potensi alam berupa padang penggembalaan yang luas dan banyaknya masyarakat yang memiliki sapi merupakan modal awalnya. Solusi yang ditawarkan pada kegiatan ini yakni peningkatan kapasistas SDM dan pemanfaatan SDA melalui penerapan teknologi tepat guna. Solusi tersebut memiliki daya ungkit yang besar dalam menyelesaikan masalah masyarakat. Secara terperinci solusi yang ditawarkan yakni: 1) Pelatihan dan pendampingan manajemen pemeliharaan sapi pada sistem pembibitan; 2) Pembuatan kebun rumput kualitas tinggi sebagai penyedia pakan dan perbaikan infrastruktur pendukung Desa Pembibitan Ternak; dan 3) Pelayanan kesehatan ternak. Secara umum pelaksanaan PPDM pada tahun 2019 merupakan rangkaian kegiatan yang telah dilaksanakan sejak tahun 2018. Pada tahun 2018 kegiatan di fokuskan pada identifikasi masalah spesifik dan inisiasi kelompok peternak sebagai kelompok pembibit pionir. Fokus kegiatan tahun 2019 yakni perbaikan infrastruktur pembibitan ternak di Desa Sentra Pembibitan Sapi Bali.

\section{MATERI DAN METODE}

Kegiatan PPDM di Desa Pattondon Salu tahun 2019 dilaksanakan dalam beberapa metode, yakni; 1) Pelatihan dan penyuluhan pada penyebaran inovasi teknologi; 2) Wawancara/ FGD dan kusioner untuk mengidentifikasi capaian pelaksanan kegiatan; 3) Demontrasi penerapan teknologi; dan 4) Recording untuk data peningkatan populasi ternak. Pelaksanaan PPDM antara lain; 1)
Pelatihan pemeliharaan induk dan pedet pasca melahirkan; 2) Pembuatan demplot/ kebun rumput gajah dan perbaikan infrastruktur pendukung Desa Pembibitan Ternak; dan 3) Pelayanan kesehatan ternak.

Jumlah peternak yang berkontribusi dalam kegiatan ini yakni Kelompok Tani Sipakatuo dan Kelompok Tani Ternak Jaya, dengan jumlah total peternak sebanyak 42 orang. Data perkembangan pelaksanaan kegiatan dikumpulkan dengan melakukan survey dan wawancara menggunakan kuesioner. Selain itu dilakukan pula focus group discussion, yaitu melakukan diskusi kelompok terarah dengan peternak, serta dilakukan wawancara secara mendalam (indepth study) kepada beberapa informan kunci. Data yang terkumpul kemudian dianalisis secara deskriptif menggunakan software Microsoft Excel 2007.

\section{SOLUSI DAN LUARAN}

\section{a. Pelatihan Pemeliharaan Induk dan Anak} Pasca Melahirkan

Kegiatan ini dilaksanakan melalui metode pelatihan dan penyuluhan yang melibatkan masyarakat sebagai anggota kelompok peternak di Desa Sentra Pembibitan Ternak (Gambar 1). Pada kegiatan ini, dipaparkan tatacara pemeliharaan sapi indukan pasca melahirkan, yakni dengan memisahkan dari populasi sapi lainnya pada kandang khusus, pemberian pakan berkualitas untuk induk yang menyusui dan penyiapan kandang khusus induk dan anak.

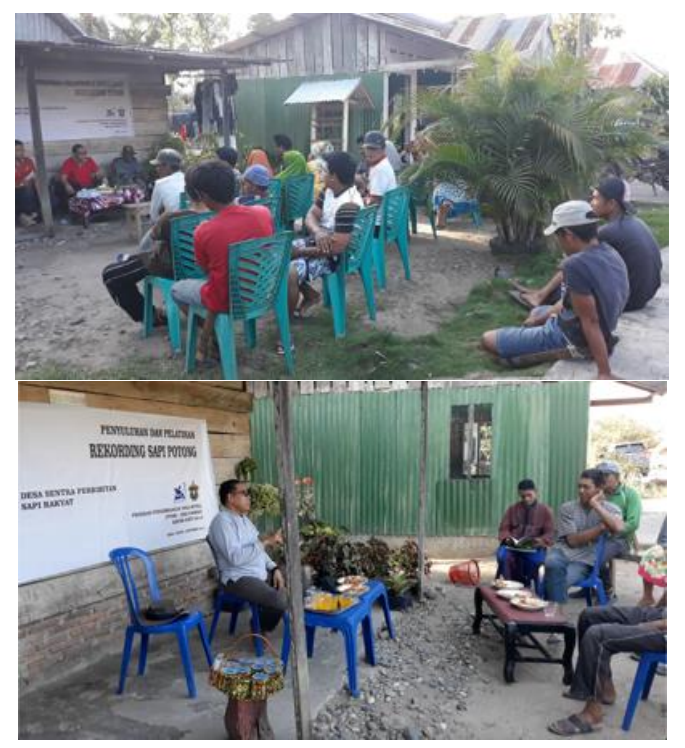

Gambar 1. Pelatihan Manajemen Pemeliharaan Sapi Induk dan Anak dan Recording pada Sistem Pembibitan Ternak

Pelatihan pada manajemen pemeliharaan ternak disistem pembibitan ternak dilaksanakan antara lain bertujuan untuk: 1) Pemahaman tatacara 
pemeliharaan induk dan pedet, pemisahan dikandang khusus hingga kebutuhan pakannya; 2) Pemaparan tata cara recording ternak pada Desa Sentra Pembibitan Ternak; dan 3) Pembagian buku recording pada masyarakat yang diikuti penjelasan mengenai cara pengisian data-data pada buku tersebut. Hasil dari kegiatan tersebut yakni beberapa peternak menerapkan pemisahan induk dan pedet dengan populasi lainnya dan melakukan recording pada saat pedet lahir. Dampak dari pelatihan yakni pada peningkatan jumlah pedet yang bertahan hidup dan menambah jumlah populasi (Gambar 2).

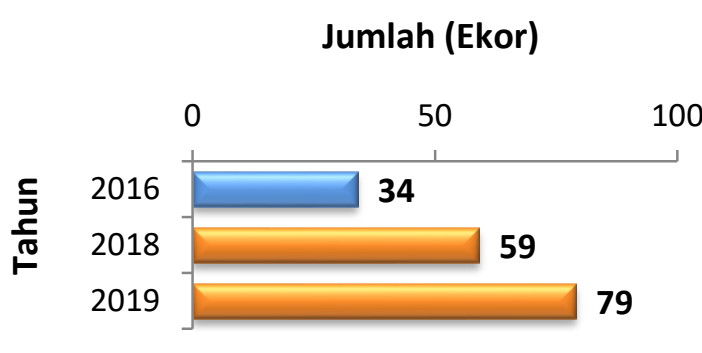

Gambar 2. Perkembangan Populasi Ternak Mitra PPDM Berdasarkan Tahun Pelaksanaan

Produktifitas ternak menjadi cerminan capaian dari pelaksanaan kegiatan PPDM tahun 2019. Gambar 2 menunjukkan adanya peningkatan jumlah ternak yang terlibat dalam kegiatan ini. Berdasarkan tahun, tahun 2019 jumlah ternak di desa mitra yang mengikuti program mencapai 79 ekor, sedangkan tahun 2018 sebanyak 59 ekor. Setiap tahunnya terjadi peningkatan jumlah ternak yang dipelihara oleh mitra. Peningkatan terjadi disebabkan semakin baiknya manajemen pemeliharaan, terutama pada penanganan sapi induk pasca melahirkan. Perkembangan populasi berupa pertambahan populasi yang berasal dari kelahiran, meskipun terjadi kematian dan penjualan yang mengurangi jumlah populasi. Pengembangan populasi sapi potong merupakan hal yang kompleks karena meliputi beberapa aspek. Upaya tersebut melalui pengembangan berbagai potensi yang ada pada peternak sapi potong baik dari aspek sosial (tingkat pendidikan, lama beternak, tenaga kerja, perilaku zooteknis usaha), ekonomi (modal) maupun teknis (lahan dan ketersediaan pakan), sehingga keberadaan usaha ternak sapi potong dapat dikembangkan secara optimal [2].

\section{b. Pembuatan Demplot Kebun Rumput dan Perbaikan Infrastruktur Pendukung}

Penambahan populasi sebagai dampak dari perbaikan manajemen pemeliharaan sapi, berkontribusi pada semakin tingginya kebutuhan pakan. Serta untuk menyelesaikan masalah rendahnya kualitas pakan, maka pembuatan demplot kebun percontohan sangat dibutuhkan oleh masyarakat. Pembuatan demplot dengan memanfaatkan lahan yang dimiliki oleh masyarakat yang terletak disekitar padang penggembalaan. Jenis tanaman yang digunakan yakni rumput gajah (Pennisetum purpureum) dikarenakan memiliki produksi yang tinggi (Gambar 3).

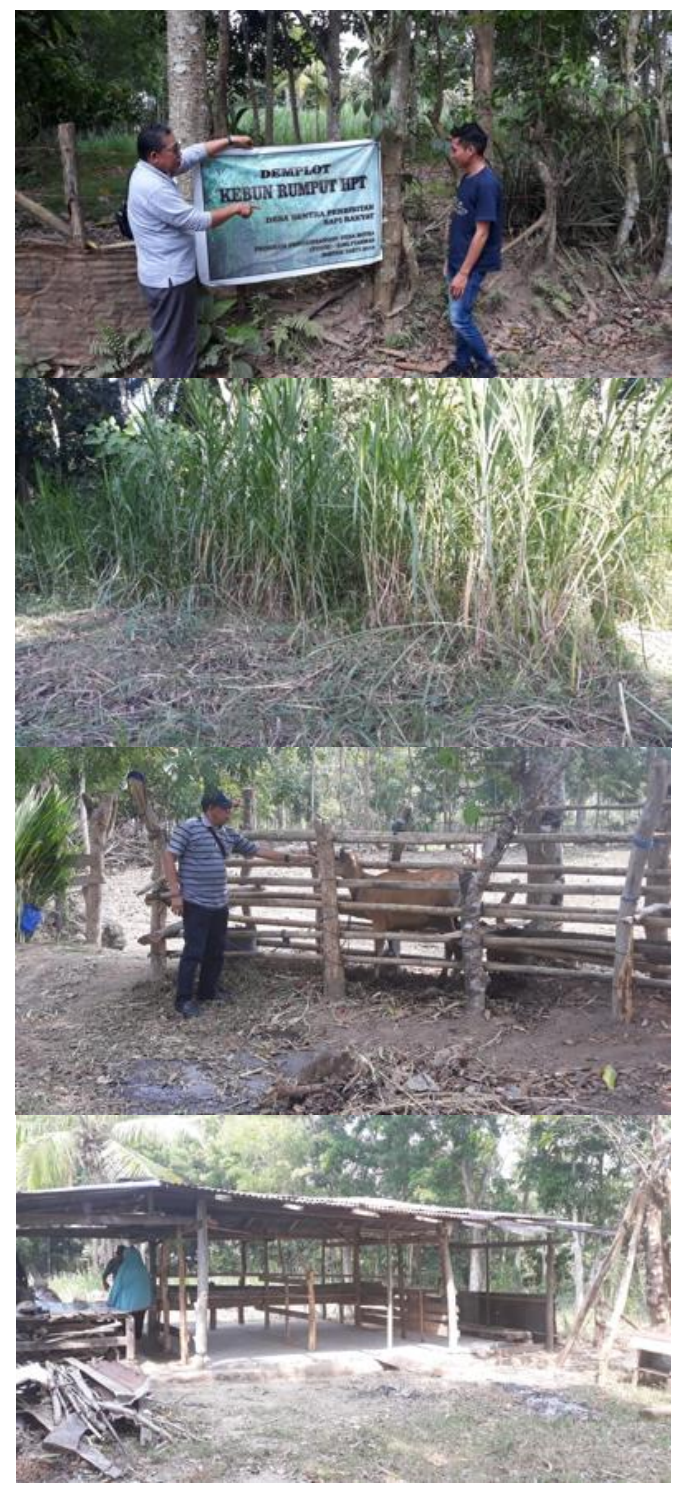

Gambar 3. Pembuatan Demplot dan Infrastruktur pendukung (Kandang Jepit dan Kandang Induk Pasca melahirkan)

Hasil yang didapatkan pada pembuatan demplot kebun rumput dan perbaikan infrastruktur pendukung yakni berdasarkan data populasi, menunjukkan jumlah pedet sapi yang bertahan hingga dewasa meningkat. Selain itu, terjadi peningkatan kebuntingan pada ternak milik masyarakat (mitra). Penggunaan infrastruktur pendukung seperti kandang induk dan pedet memberikan jaminan kesehatan pada induk dan pedet dikarenakan terpisah dari populasi lainnya. Kondisi birahi sapi induk pasca melahirkan juga 
berjalan secara normal, yang ditandai pada meningkatnya persentase kebuntingan di tahun 2019 (Gambar 4).

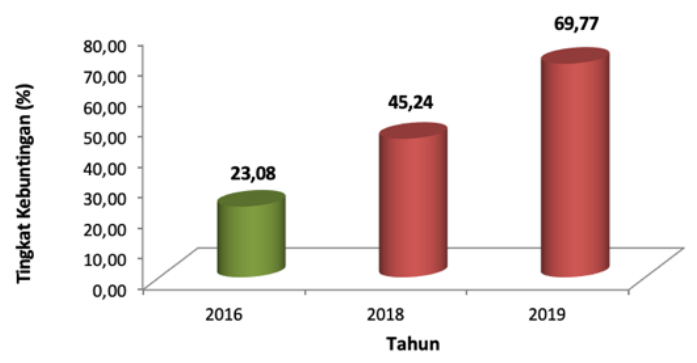

Gambar 4. Tingkat Kebuntingan Ternak Mitra tahun 2016 2019

Berdasarkan Gambar 4 tingkat kebuntingan semakin meningkat tiap tahunnya. Kondisi tahun 2016 dimana peternak belum mendapatkan pendampingan melalui kegiatan PPDM, tingkat kebuntingan hanya mencapai 23,08\%, sedangkan tahun 2018 dimana pelaksanaan kegiatan PPDM tahap I mencapai $45,24 \%$ atau meningkat $22,16 \%$ dari tahun sebelumnya. Pencapaian pelaksanaan kegiatan di tahun 2019 per bulan mencapai $69,77 \%$ atau meningkat $24,53 \%$ dari tahun sebelumnya. Secara keseluruhan, masyarakat telah menikmati manfaat pelaksanaan PPDM 2018 - 2019.

\section{c. Pelayanan kesehatan ternak}

Kesehatan ternak menjadi perhatian penting pada pelaksanaan PPDM tahun 2019, fokus jenis penyakit yang ditangani adalah penyakit yang menjangkiti ternak yang dipelihara pada sistem penggembalan (semi intensif). Pengobatan dan pencegahan penyakit yang banyak dilakukan yakni pemberian obat cacing dan vitamin B kompleks. Infeksi cacing memberikan dampak yang buruk pada peternakan rakyat, hingga memberikan kerugian ekonomi. Infeksi cacing pada saluran pencernaan sapi mengakibatkan gangguan pencernaan dan menyebabkan terjadinya kompetisi dalam penyerapan nutrisi makanan [3].

Pengendalian penyakit cacing dilakukan bukan hanya dalam rangka menjaga kesehatan ternak, namun juga penyakit ini bersifat zoonosis. Penyakit ini menyerang disegala umur ternak sapi dan banyak ditemukan pada pedet. Dampak negatif dari penyakit ini dapat menekan produktifitas ternak, pedet yang menderita toxocariasis, akan kehilangan bobot badan. Beberapa contoh prevelansi penyakit tersebut sebesar $76 \%$ di Malang [4]. Sedangkan di Surabaya pada anak sapi umur kurang dari 2 bulan prevalensinya adalah $68,2 \%$ dan umur kurang dari 6 bulan mencapai $43,4 \%$ [5].
Permasalahan yang sering dihadapi dari toxocariasis adalah sulitnya diagnosis penyakit tersebut sedini mungkin. Hal ini disebabkan karena larva kedua (L2) Toxocara yang berada di dalam tubuh hospes paratenik dan hospes transpor seperti cacing tanah, kecoa, ayam, anak kambing dan khususnya manusia tidak pernah berkembang menjadi larva tiga (L3) [5]. Dalam tubuh induk semang larva tidak dapat berkembang menjadi cacing dewasa dan tetap tinggal di jaringan sebagai L2 dorman, Sehingga tidak dapat dilakukan pemeriksaan secara konvensional dengan cara menemukan telur cacing di dalam feses untuk menetapkan diagnosis [6].

Pengendalian penyakit pada PPDM tahun 2019 diimplementasikan pada 3 (tiga) kegiatan pokok, yakni: 1) penyuluhan mengenai pengendalian penyakit sapi; 2) pencegahan dengan pemberian vitamin $\mathrm{B}$ untuk menstimulus pertumbuhan dan antibodi; dan 3) pengobatan menggunakan antibiotik. Kegiatan tersebut dilaksanakan pada bulan Agustus - Desember 2019 (Gambar 5).

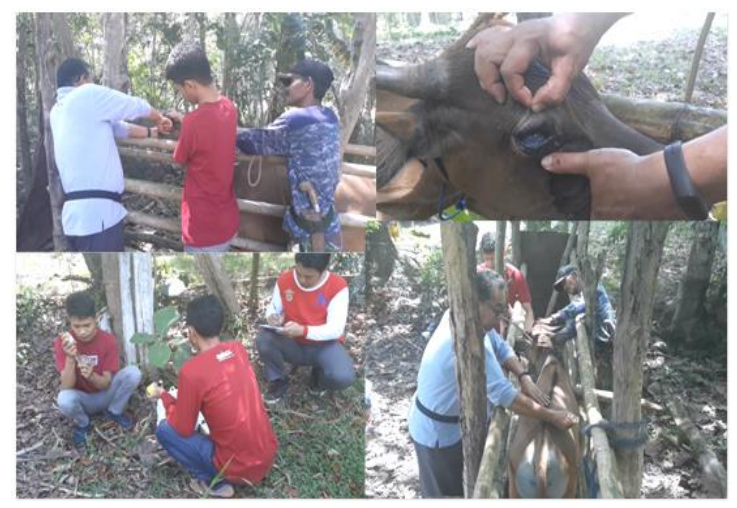

Gambar 5. Kegiatan Pengendalian Penyakit PPDM 2019

\section{KESIMPULAN}

Perbaikan manajemen pemeliharaan ternak khususnya induk pasca melahirkan dilakukan untuk meningkatkan populasi ternak. Perbaikan pakan melalui pembuatan kebun rumput gajah dan perbaikan infrastruktur perkandangan telah dilakukan untuk mendukung kegiatan pembibitan ternak. Perbaikan kesehatan dilaksanakan pada penyakit yang paling sering ditemukan pada ternak, yakni toxocariasis.

\section{UCAPAN TERIMA KASIH}

Penulis mengucapkan terimakasih kepada Direktorat Riset dan Pengembangan KemenristekDIKTI yang telah memberikan dukungan pendanaan selama berlangsungnya Program Pengembangan Desa Mitra tahun 2019 ini. 


\section{DAFTAR PUSTAKA}

[1] Badan Pusat Statistik. 2015. Kabupaten Enrekang dalam Angka 2015. Enrekang: Badan Pusat Statistik Kabupaten Enrekang.

[2] Mukson, S. Marzuki, P. I. Sai. Dan H.Setiawan. 2008. Faktor-Faktor Yang Mempegaruhi Potensi Pengembangan Ternak Sapi Potong Rakyat Di Kecamatan Kaliori, Kabupaten Rembang, Jawa Tengah. J. Indon. Trop. Anim. Agric. Vol. 33 (4).

[3] Agustina, K.K., A.A.G.O. Dharmayudha dan IW. Wirata. 2013. Prevalensi Toxocara vitulorum Pada Induk Dan Anak Sapi Bali Di Wilayah Bali Timur. Buletin Veteriner Udayana. Volume 5 No. 1 : 1-6.

[4] Trisunuwati, P., T. Cornelissen and Nasich. 1991 . A parasitological study on the impact of Nematodes on the production of livestock in the limestone area of South Malang. Interdiciplinary Res. J. Landbouw Agric. Univ. Wageningen. The Netherlands.

[5] Koesdarto, S., S. Uga, Machfudz, S.S. Mumpuni, Kusnoto and H. Puspitawati. 1999. The prevalence of Toxocara vitulorum in dairy cows in Surabaya. Proc - Seminar on Infectious Diseases in The Tropics . TDC Airlangga University, Surabaya . P. 46-49.

[6] Starke, W.A., R.Z. Machado., G.H. Bechara and M.C. Zocoller. 1996. Skin Hypersensitivity Test in Buffaloes Parasitizes with Toxocara vitulorum. Vet Parasitol; 63(3-4): 283-90. 
Jati Emas (Jurnal Aplikasi Teknik dan Pengabdian Masyarakat)

Vol. 4 No. 2 Oktober 2020 - e. ISSN: 2550-0821 